\title{
One Thousand Faces of Langerhans Islets
}

\author{
Parviz M. Pour ${ }^{*}, 1$ and Bruno M. Schmied ${ }^{2}$ \\ ${ }^{\prime}$ The Eppley Institute for Research in Cancer and Allied Diseases and Department of Pathology and Microbiology, \\ University of Nebraska Medial Center, Omaha, NE; and ${ }^{2}$ Visceral and Transplantation Surgery, \\ Inselspital, Bern, Switzerland
}

\begin{abstract}
Summary
Studies with different strains of Syrian hamsters and Syrian golden hamsters have revealed the remarkable potential of islet cells to undergo orthotopic and heterotopic metaplasia. The most common spontaneous change included the development of hepatocytes in aged and malnourished hamsters. Of the many other alterations that occurred during carcinogenesis, most of the metaplastic changes originated within the islet periphery and progressed inside and outside the islets. The development of ductular structures within islets and their progression either to structures identical to human serous cystadenoma or to highly invasive adenocarcinomas were the most common alterations. The remarkably greater invasive potential of cancer cells arising within the islets contrasted sharply with the slow growth of the tumors developing within ducts (intraductal tumors). Studies in human tissue also showed development of malignant cells within islets, and, in some cases, transition of islet cells to malignant cells was suggested. The overall results, along with recent findings in other studies in cultured human and hamster islets, indicate the enormous potential of islet cells to differentiate and undergo malignant transformation. Whether the metaplastic and malignant cells derive from stem cells embedded within islets or from transdifferentiated islet cells remains to be seen.
\end{abstract}

Key Words: Islet; metaplasia; differentiation; cancer; hamster; human.

\section{Introduction}

The endocrine pancreas still presents a physiological, biological, and pathophysiological puzzle. Although its derivation from endoderm has been accepted, its embryological and postfetal development, and macro- and microdomains are poorly understood. Its fairly consistent distribution within the exocrine pancreas of all mammals and its remarkably similar size, which is in most mammals independent of the body size, reflect a global effect of

Received December 8, 1998; Revised March 1, 1999; Accepted March 30, 1999

Address to which all correspondence and reprint requests should be addressed: UNMC/Eppley Cancer Center, University of Nebraska Medical Center, 986805 Nebraska Medical Center, Omaha, NE68198-6805. E-mail: ppour@mail.unmc.edu islets and their unique physiological role. The specific spatial distribution of individual hormoneproducing cells within islets, the cell heterogeneity, species differences in the cellular arrangements, and their paracrine interaction have remained a mystery, as have the differences in its cellular composition in tissues derived from the ventral and dorsal pancreatic anlage. The production of known and yet some unknown hormones by individual cells and the synthesis of several agonistic or antagonistic hormones, even in the same cell (i.e., insulin and amylin), add to the physiological complexity of the islets.

As early as 1927, Neurbert et al. (1) reported on the presence of two types of islets in humans. One completely separated from the surrounding tissue and the other intimately connected with the exocrine cells. Although the existence of an intimate dialog between the endocrine and exocrine pancreas has 
been recognized, the magnitude of this interaction and its mechanisms are unclear. It has been generally accepted that the renewal of islet cells occurs primarily from ductal/ductular cells. However, the molecular mechanism of this event is unclear. The questions regarding whether islet cells originate from mature ductal/ductular cells or from undifferentiated (reserve, stem) cells residing within the ductal epithelium has not been answered. The pioneer work of Bencosme, Boquist, Lazarus and Volk, and Ferner and Laidlaw (2-6) has demonstrated the presence of a heterogenous cell population within the islets. According to their work, islet cells originate from undifferentiated cells termed variously as "Helle Zellen" (5), islet cell precursors (2), or nesidioblasts (6).

Historically, the first anatomical signs for endocrine-exocrine interaction were recognized by Bensley in 1911 (7), who by using a meticulous technique showed that some islets of Guinea pigs are pierced through by ductules and that the ductular cells within islets have close contact with islet cells. This finding was ignored possibly because the observation did not fit with the existing concept at that time, when ectodermal origin of islets was favored. Bloom and Fawcet, in 1968 (8), confirmed Bensley's finding in humans, as we did in 1978 in Syrian golden hamsters (9). Although in hamsters, the "intrainsular" ductules were not present or visible in healthy animals, they developed in aged hamsters and were particularly dominant in animals treated with pancreatic carcinogens (9-11).

During 24 years of pancreatic cancer research using animal models and human tissues, we have accumulated data suggesting the existence of a pluripotent cell population within the islets capable of producing not only endocrine and exocrine cells, but also heterotopic cells of hepato-gastrointestinal origin. In the following, the many changes of islet cells in Syrian hamsters and in humans are summarized and discussed.

\section{Materials and Methods}

Pancreatic tissues derived from our studies were used to investigate spontaneous diseases in four strains of Syrian hamsters, golden, yellow, white, and albino (12), and from several carcinogenicity experiments with $N$-nitrosobis(2-oxopropyl)amine (BOP). Human pancreatic tissues were obtained from previously reported studies $(10,13-16)$. The tissues were fixed either in Bouin solution or in buffered formalin, and processed for histology according to conventional methods. From a few pancreatic tissues, frozen sections were prepared for demonstration of glycogen. Each hamster pancreas was cut

\section{See art on facing page}

Fig. 1. The pancreas of a 65 -week-old Syrian golden hamster is showing single eosinophilic cells with an abundant cytoplasm in the periphery of an islet (arrowheads). (H\&E $\times 210)$.

Fig. 2. An islet of a white Syrian hamster with a group of "hepatocytes (arrows)." A portion of another islet, partially replaced by the hepatocytes, is seen at the lower left corner. $(H \& E \times 210)$.

Fig. 3. Two islets of a Syrian hamster treated with selenium and a high-fat diet. Almost complete replacement of the islet cells by the hepatocytes. Some hepatocytes were reactive with antisomatostatin (inset). H\&E $\times 190$. Inset: antisomatostatin, $\mathrm{ABC}$ method $\times 190$.

Fig. 4. A mixture of hepatocytes and glandular structures in the pancreas of an aged Albino Syrian hamster. Note formation of glandular structures by the hepatocytes $(*)(H \& E \times 130)$.

Fig. 5. Hepatocytes occupying a fairly large area of the pancreas of an aged yellow Syrian hamster. Immunohistochemistry shows remnants of islet cells (black). (H\&E $\times 130)$.

Fig. 6. Fat droplets within hepatocytes surrounded by lipocytes. Gradual transformation of hepatocytes to fat cells was seen in many areas. Albino Syrian hamster $(H \& E \times 250)$.

Fig. 7. Cells resembling oncocytes have replaced three adjacent islets (I). Immunohistochemistry revealed the presence of a few $\beta$ cells within the lesion. A BOP-treated Syrian golden hamster $(H \& E \times 120)$.

Fig. 8. Cells with ground glass appearance within an islet of a BOP-treated Syrian golden hamster. Note the impression of the gradual transformation of islet cells to other cells ( $\mathrm{H} \& \mathrm{E} \times 210)$. 


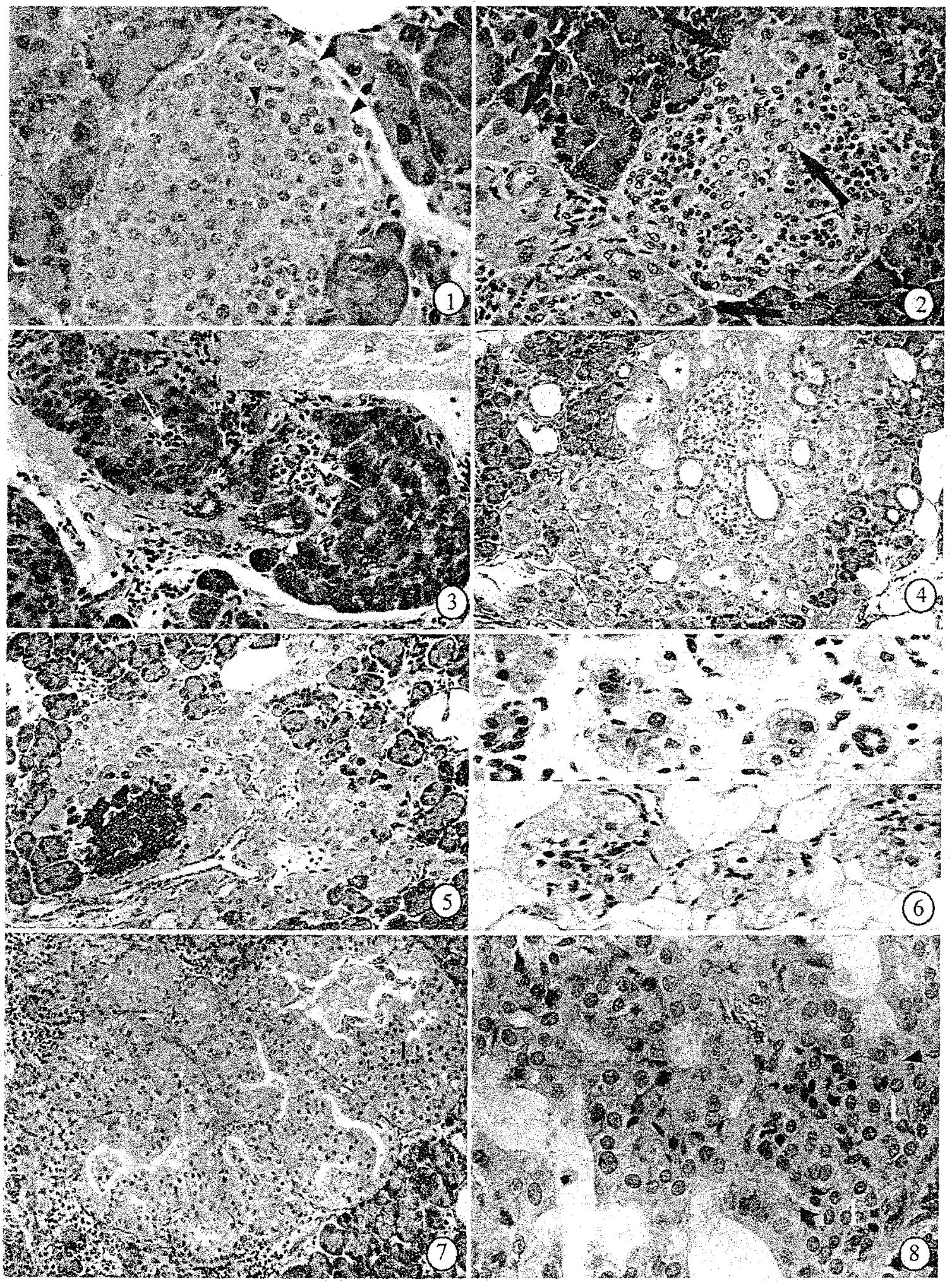




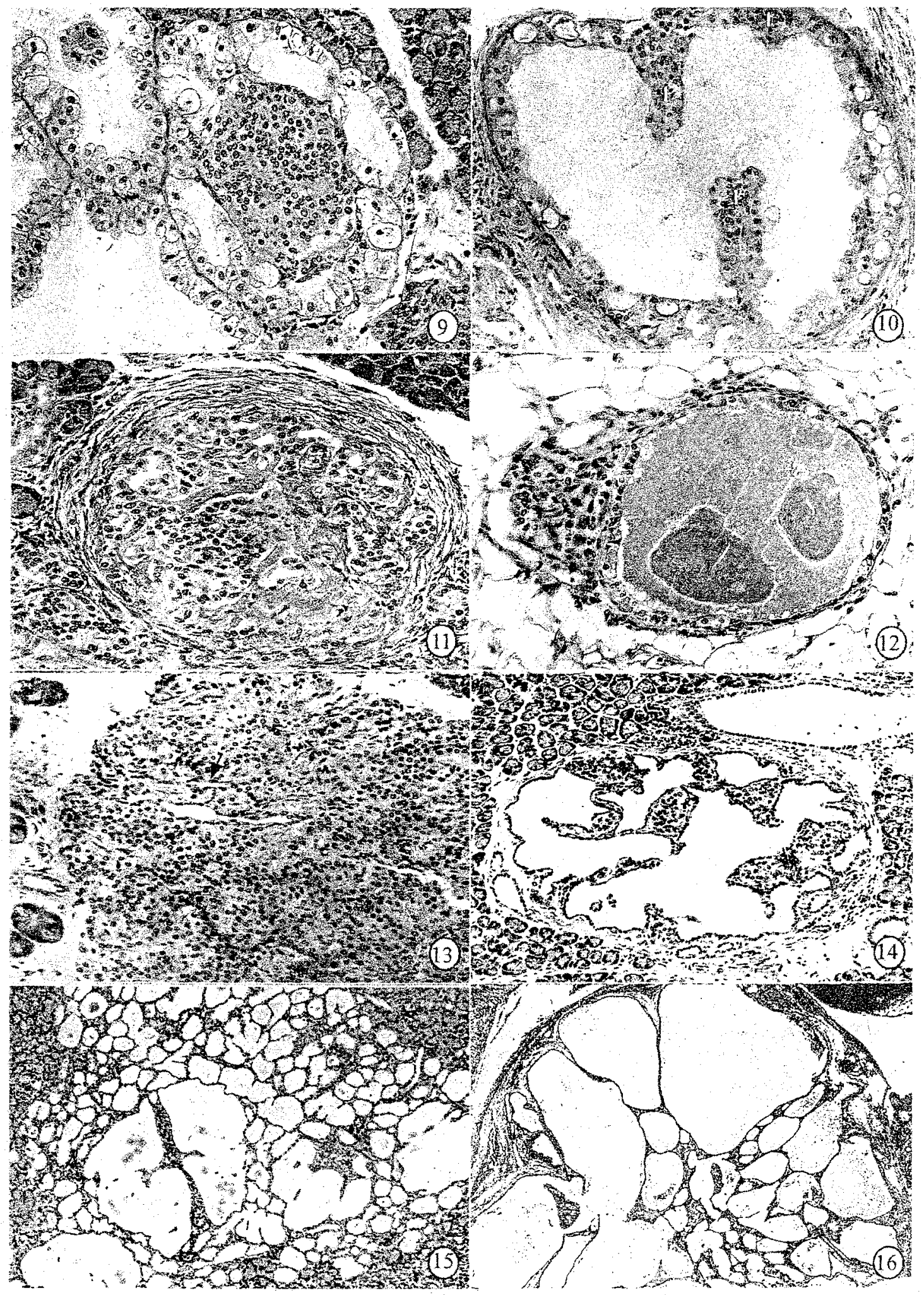


into 6-12-step sections, and those of humans into 300-3200 sections. Sections were stained with hematoxyllin and eosin and, in some cases, also with antibodies against islet hormones or by histochemistry for demonstration of amylin and glycogen.

\section{Results}

By comparing the spontaneous disease of the pancreas in four strains of Syrian hamsters, we observed large eosinophilic cells resembling hepatocytes in aged hamsters, particularly more common and prominent in the White strain (12). These hepatocyte-like cells appeared initially in the peripheral zone of islets as a single or a small group of cells (Fig. 1). From there, they progressed inside the islets (Fig. 2) to form spherical conglomerates corresponding to the size of affected islets with a few or no islet cells in the center of the conglomerates (Fig. 3). Often, several neighboring islets and/or islets in different pancreatic regions were affected. In advanced cases, the alteration extended into surrounding pancreatic areas and involved the epithelium of ductules or formed, per se, glandular structures (Fig. 4). Between these cells, scattered islet cells could be identified immunohistochemically (Fig. 5). In a few cases, some of the hepatocyte-like cells reacted with antisomatostatin (Fig. 3 ), but not with antibodies against insulin and glucagon. Remarkably, the appearance of these cells always coincided with lipomatosis of the pancreas.
Like hepatocytes in fat-liver disease, these cells accumulated fat droplets and culminated in cells indistinguishable from the surrounding lipocytes (Fig. 6).

Although the development of hepatocytes is seemingly a degenerative process, we observed other metaplastic changes that occurred only in hamsters treated with the pancreatic carciogen BOP. Like hepatocytes, cells resembling oncocytes developed in the islet periphery and ultimately occupied the whole islet or several neighboring islets (Fig. 7) with only a few remnant intact islet cells detectable within them.

In some experiments, especially in those where formation of new islets (nesidioblastosis) was stimulated before BOP treatment (17), a fairly large spectrum of metaplastic changes could be seen. Formation of cells with a ground-glass appearance was one of these changes (Fig. 8). In these lesions, gradual transformation of islet cells to the metaplastic cells was suggested (Fig. 8). Other metaplastic changes included clear cells (Fig. 9), mucinous cells (Fig. 10), goblet-like cells, cells with opaque-appearing cytoplasm (Fig. 11), or a combination of above. The opaque cells forming small glandular structures were, in some cases, separated from each other by amyloid-like material (Fig. 11) not reactive with the relative staining procedures. All of these lesions also appeared first in the islet periphery. In the atrophic region of the pancreas, owing to ductal obstruction, single or multiple cysts lined by various cell types were also observed (Fig. 12).

\section{See art on opposite page}

Fig. 9. Small glands lined by clear cells at the periphery of a BOP-treated Syrian golden hamster. Close to this islet, several ductular structures were replace by the clear cells $(H \& E \times 210)$.

Fig. 10. A mixture of goblet-like and cuboidal cells forming a large cyst within an islet of a BOP-treated hamster. The remnant of islet cells are seen (I) $(H \& E \times 210)$.

Fig. 11. Irregular glandular structures separated by bands of hyaline-like material. No evidence for amyloid deposition could be found. This lesions was confined to one islet. A BOP-treated hamster $(\mathrm{H} \& \mathrm{E} \times 210)$.

Fig. 12. A large cyst lined by flat or cuboidal cells within an islet in the atrophic pancreatic region of a BOP-treated hamster. This hamster had a large cancer in the head of the pancreas $(H \& E \times 210)$.

Fig. 13. Tiny ductular structures (arrow) within an enlarged islet of a hamster treated with BOP. This was the only alteration found in the pancreas of this hamster (H\&E x 165).

Fig. 14. Ramified and distended ductular structures with an islet of a BOP-treated hamster. There were no other lesions identifiable $(\mathrm{H} \& \mathrm{E} \times 65)$.

Fig. 15. Formation of microcystic structures within several neighboring islets and in their surrounding tissues, giving the impression of human microcystic adenoma ( $\mathrm{H} \& \mathrm{E} \times 110)$.

Fig. 16. A multicystic lesion in the pancreas of a hamster treated with BOP. The encapsulated lesion is comparable to human serous cystadenoma $(\mathrm{H} \& \mathrm{E} \times 65)$. 
The most striking and consistent changes in BOPtreated hamsters were the development of ductular structures within islets. These changes occurred much earlier than any other alterations in the ductal system. Initially, the tiny, difficult-to-discern channels developed at the periphery or the center of islets (Fig. 13). At later stages, these channels expanded, ramified, and formed complex structures that gradually occupied the entire islet (Fig. 14) and culminated in microcystic or macrocystic patterns consistent with human serous cystadenomas (Figs. 15 and 16). In other islets, the intrainsular ductular cells appeared hyperplastic from their inception (Fig. 17), atypical (Fig. 18), or malignant, occupying part of or the entire islets, and invading the surrounding tissue even at their microscopic size (Fig. 19). In hamsters treated with high doses of the carcinogen, a single or a small group of pleomorphic malignant cells forming bizarre glandular structures appeared at early carcinogenesis process (Figs. 20 and 21). Electron microscopical examination of such a lesion showed that ductular structures contained scattered neuroendocrine granules (Fig. 22).

The differentiation pathway of islet cells seems to be altered in pathological conditions, particularly in response to carcinogens, including streptozotocin. This diabetogenic and carcinogenic compound selectively destroys the $\beta$-cells in many species and leads to a peculiar honeycomb pattern of islets owing to swelling and glycogen accumulation in the $\beta$-cells (Fig. 23). In animals recovering from diabetes, pleomorphic and bizarre cells develop in the periphery of islets (Fig. 24), and give rise to tumors of various cellular composition (18), adding to the spectrum of phenotypic displays of islets.

The described islet alterations and other confirmatory findings not included in this article show that in hamsters most pancreatic tumors of endocrine or exocrine phenotype, arise from within islets. Therefore, it is ironic to see that the endocrine pancreas "gives birth" to exocrine pancreatic cancer. Anecdotal observations indicate the situation is not different in humans.

Following our experimental observation, we paid particular attention to the islets of patients with pancreatic cancer and by evaluating more than $3200 \mathrm{sec}-$ tions/pancreas could confirm Warren's finding (41). As in hamsters, intrainsular ductules could be found in patients with pancreatic diseases, especially chronic pancreatitis and pancreatic cancer (Fig. 25), but malignant cells have been identified only in patients with pancreatic cancer. Strikingly, these lesions, also developed in the islet periphery (Fig. 26), were present not only in the vicinity of cancers, but also in the tail of the pancreas, very remote from the primary cancers in the pancreas head $(10,24)$. As illustrated in Figs. 26 and 27, no connection could be found between the malignant intrainsular cells and the surrounding tissue, which in most cases was fibrotic or scarred. As in the hamster model, small groups of malignant cells forming abortive glandular structures were also found in areas free of cancer (Figs. 28 and 29). In two pancreatic cancer patients with atrophic and scarred tail portions of the pancreas, the fragmented islets were abruptly interrupted by a single or small groups of malignant cells.

See art on facing page

Fig. 17. Tiny ductular structures with hyperplastic ducts found during early stages of carcinogenesis within an islet. Note the hepatocytes in the islet periphery (arrow) $(H \& E \times 65)$.

Fig. 18. Atypical ductular structures with hyperplastic epithelium replacing most of the islet cells (I) $(H \& E \times 190)$.

Fig. 19. Malignant ductular structures within an islet invading the surrounding tissue in a BOP-treated hamster (H\&E $\times 190)$.

Fig. 20. A few, malignant-appearing cells within a small hamster islet forming a minute lumen (*) $(\mathrm{H} \& \mathrm{E} \times 210)$.

Fig. 21. A malignant gland within a small islet of a BOP-treated hamster $(H \& E \times 210)$.

Fig. 22. Electron microscopical finding of a well-differentiated pancreatic cancer showing focal accumulation of neuroendocrine-like granules (arrowheads) $(\times 3500)$.

Fig. 23. Pancreatic islet of a hamster treated with streptozotocin. Ballooning of many islet cells. Frozen section demonstrated glycogen within the empty-looking cells $(\mathrm{H} \& \mathrm{E} \times 2 \mathrm{~L} 0)$.

Fig. 24. An islet of a hamster treated with streptozotocin 20 wk earlier. Note atypical pleomorphic cells occupying almost onehalf of the islet $(\mathrm{H} \& \mathrm{E} \times 210)$. 


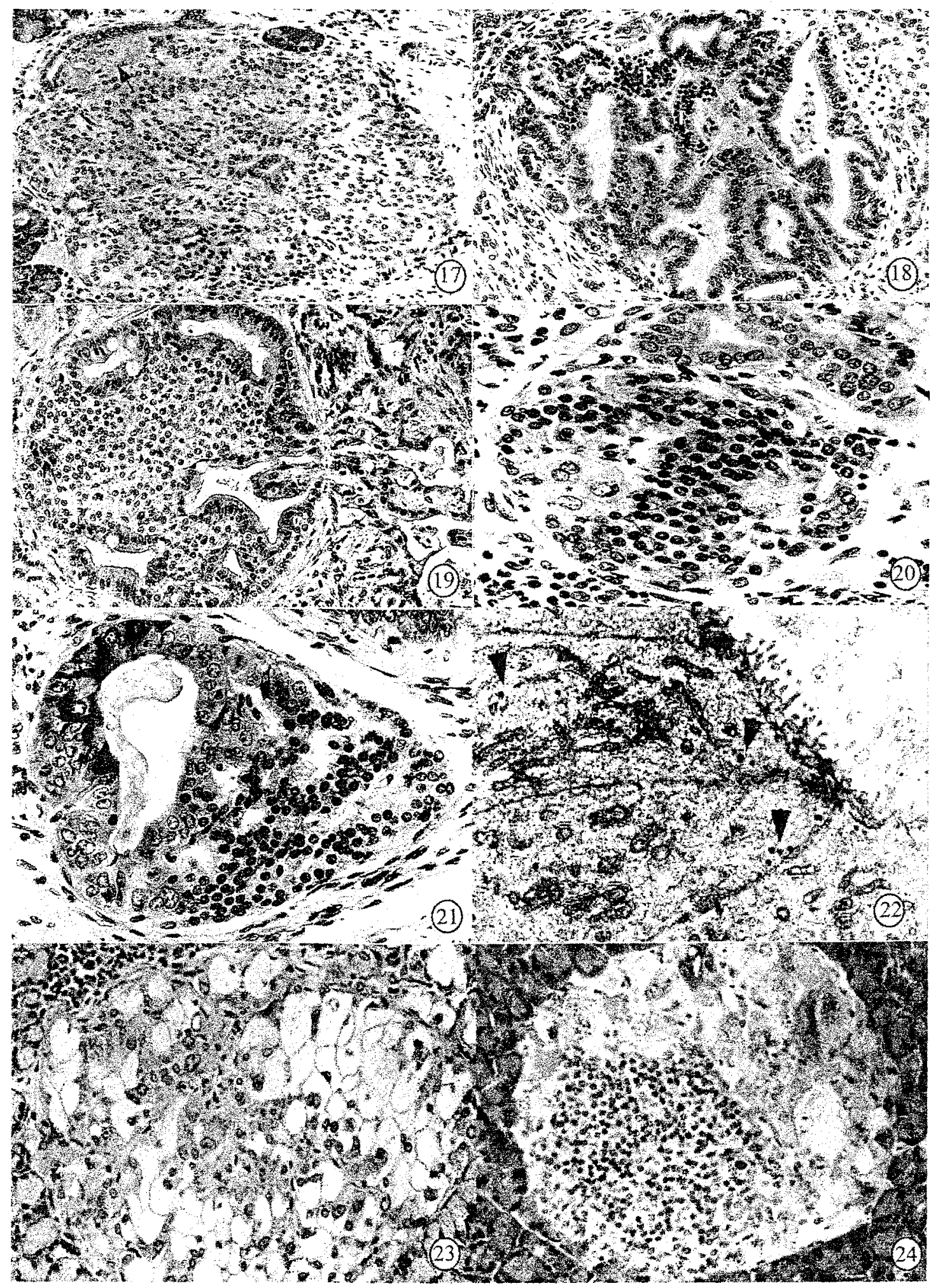




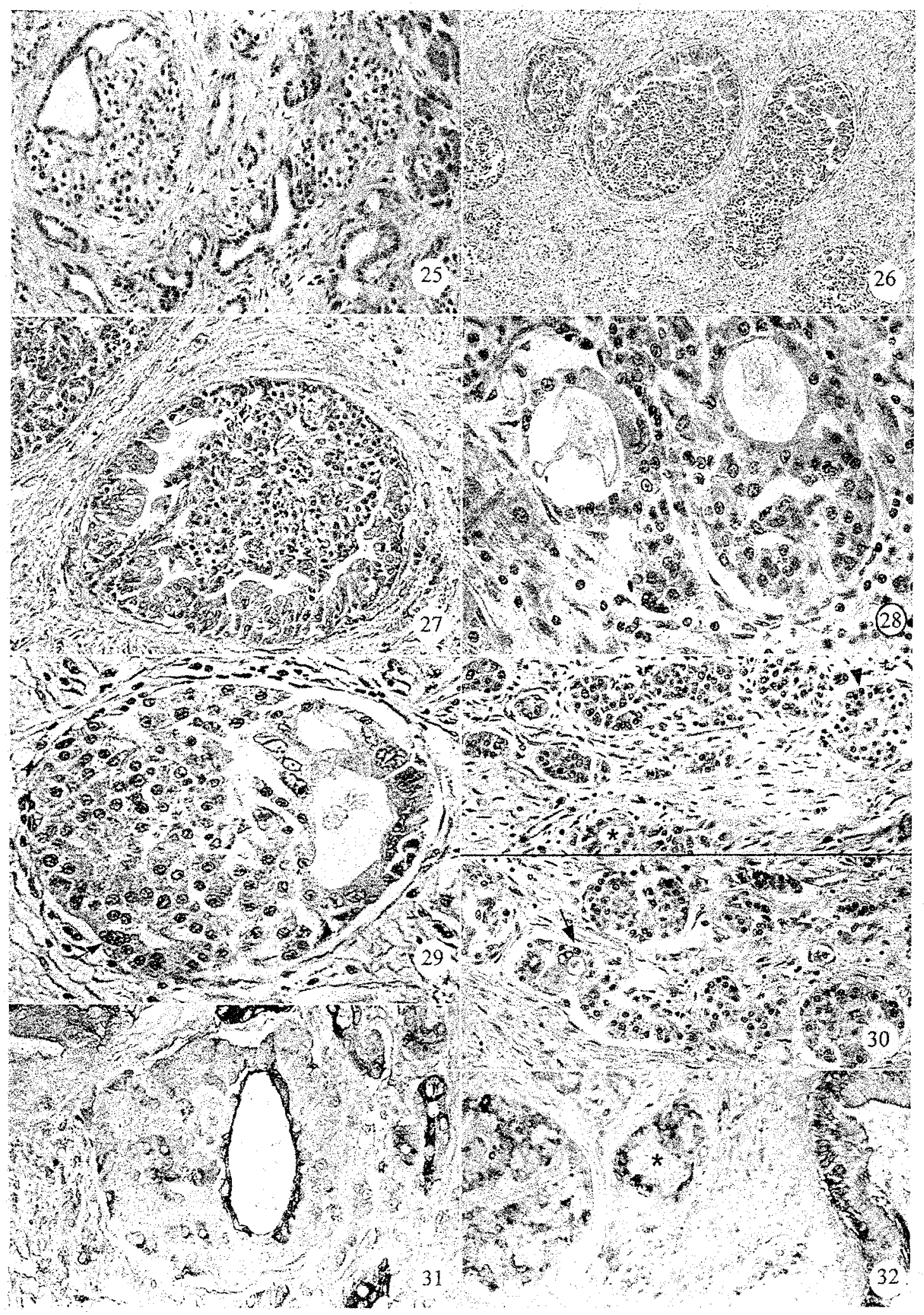


Many islets also showed a pattern suggesting gradual transformation of islet cells into malignant cells (Fig. 30).

Other noteworthy alterations of islets in pancreatic cancer patients included the expression of tumorassociated antigens (TAG72, CA 19-9, DU-PAN-2) and loss of immunoreactivity to antihormone antibodies in islets close to or remote from cancers (Figs. 31 and 32). Some of these islets were partially or completely replaced by ductular structures, the cell linings of which expressed the same antigen (Figs. 31 and 32), indicating that either islet cells transdifferentiate into ductular phenotype or the differentiation pathway of islet precursor cells has been switched into the ductal cell lineage.

\section{Discussion}

The plasticity of ductal cells to undergo a spectrum of metaplastic changes has been observed by many investigators, especially in tumors that supposedly originated from ductal cells (19). According to Feyrter, the switch in the differentiation pathway is inherent to acinar cells also, which may even give rise to islet cells (20). However, the ability of islet cells to differentiate into exocrine cell lin- eage was recognized much later and was initially found to be limited to the formation of amphicrine cells containing both neuroendocrine granules and mucin $(21-23)$. Although intermediary cells have been observed in the pancreas of many species, including humans (24), the overall concept was that they develop from pancreatic stem cells through a dual differentiation pathway.

We have found that at least in the hamster, that the potential of islet cells to undergo metaplastic changes is as great as that of ductal cells. The most common phenotypic change in untreated hamsters were differentiation toward hepatocyte cell lineage. Our original observation was later confirmed by Scarpelli and Rao, who found the same lesions in younger hamsters treated with the pancreatic carcinogens (25) and showed that these cells were morphologically and biologically identical to hepatocytes. They also found that these "pancreatic hepatocytes" can be induced in a copper-depleted diet in hamsters and rats (26). Cadmium chloride in rats could produce the same lesion (27). All these observations suggest malnutrition as an etiological factor. Remarkably, similar cells have been observed recently in human fetal pancreas (28), indicating that this change is not restricted to animals.

See art on opposite page

Fig. 25. A bottle-shaped intrainsular ductular structure in a patient with chronic pancreatitis $(\mathrm{H} \& \mathrm{E} \times 110)$.

Fig. 26. Malignant cells in the periphery of several neighboring islets embedded in fibrotic stroma in the pancreas tail. Note the tumor free periinsular region (H\&E $\times 65)$.

Fig. 27. An islet in the tail of the pancreas of a 72-yr-old man with cancer in the head of the pancreas. The surrounding tissue was scarred, and there were no tumor cells around. Note the arrangement of cancer cells along the islet periphery. Part of another altered islet in the upper left corner $(H \& E \times 165)$.

Fig. 28. Small atypical glandular structures within two adjacent islets. Although the cells lining the gland in the right islets resembles islet cells, the tumor cell in the left islet are long and bridges separated islet cell groups $(\mathrm{H} \& \mathrm{E} \times 210)$.

Fig. 29. A malignant gland in the periphery of an islets in the scarred tail of the pancreas in a 68 -yr-old male with a $2.5 \mathrm{~mm}$ cancer in the head region. Apparent transtion of islet cells to malignant cells $(\mathrm{H} \& \mathrm{E} \times 210)$.

Fig. 30. Fragmented islets in the atrophic tail of the pancreas of a 65 -yr-old man with a cancer in the body-head region. The step sections did not reveal any connections between these lesions and the cancer. Note apparent replacement of islet cells by malignant cells with formation of a ductular structure $\left(^{*}\right)$ and the presence of a few atypical cells within an islet (arrowhead). The continuation of some islets was interrupted by a single or small group of cancer cells (arrow) $(\mathrm{H} \& \mathrm{E} \times 210)$.

Fig. 31. An islet in a 53-yr-old male with a cancer in the pancreas body. Note the presence of an intrainsular ductular structure, the cells of which are stained (black) with anti-DU-PAN-2 antibody. The same reactivity is seen in a few islet cells and in cancer cells around the islet. ABC method $(\times 210)$.

Fig. 32. A Strong immunoreactivity of many islet cells (left and middle) and cancer cells (right) with anti-CA 19-9 antibody. Note the formation of a glandular structure within the small islet $\left(^{*}\right)$. ABC method $(\times 210)$. 
A wide spectrum of phenotypical changes of islet cells observed in BOP-treated hamsters were similar to those found in benign and malignant lesions of ductal cell origin. Many heterotropic phenotypes, including oncocytes and clear cells, have been found in human pancreatic lesions. Oncocytes are characterized by the epithelial cell, the cytoplasms of which are filled with mitochondriae that in the routine $H \& E$ preparations give the cells a fine granular appearance. These cells have been described in hyperplastic and neoplastic human islets (29), in human ductal epithelium (30), in papillary-cystic tumors (31), or as oncocytoma composed entirely of oncocytes $(32,33)$. Similarly, tumors of clear-cell character have been observed occasionally in human pancreatic cancers (34).

A consistent change in the pancreas of BOPtreated hamsters was formation of benign and malignant ductular structures within islets. The origin of these structures from cells within the islets has been convincingly illustrated in cultured islets. In these cultures, the initially pure human and hamster islets free of intrainsular ductular components formed not only cells of ductular phenotype but also acinar, intermediary, and oncocyte cells shortly after culturing (35). Development of ductules within cultured human islets have also been reported (36-38). These data point to the pluripotent nature of some cell components within islets, possibly representing islet precursor cells (2-4), Helle Zellen (5), reserve cells, or nesidioblasts (6). However, transdifferentiation of islet cells to exocrine cell phenotype has also been suggested (37).

Formation of malignant ductular (glandular) structures within islets is of particular interest, because it is generally believed that pancreatic cancer of ductal morphology arises from ductal epithelium. The development of tumors initially within islets before any ductal alterations indicates that the reserve (stem) cells within the islets are more vulnerable to malignant transformation than the cells within ductal epithelium. It is also possible that the intrainsular lesions have a growth advantage because of their direct exposure to growth factors produced by islet cells. This possibility was validated in one of our most recent studies. When we transplanted freshly isolated hamster islets into the submandibular gland (a nontarget tissue of BOP) of recipient hamsters, highly invasive and metastatic cancers originating from islets developed $4 \mathrm{wk}$ after BOP treatment (39), the shortest latency of pancreatic cancer ever pro- duced. In the hamster pancreas, the same dose of the carcinogen produces equivalent cancers no earlier than $20 \mathrm{wk}(10)$. The significantly faster growth of tumors within the submandibular gland than in the pancreas could have been owing to the additional growth-promoting effect of epidermal growth factor within this gland. Nevertheless, the rapid growth and invasive potential of the intrainsular ductular structures contrast sharply with the late development and slow growth of lesions developing within the ductal system. Morphologically and biologically, these intraductal tumors are almost identical to human intraductal (papillary, mucinous) tumors (40). Differences between the intrainsular and intraductal tumors do not indicate etiological differences, at least in hamsters, but rather differences in the location of the tumors that may dictate tumor cell growth.

Nevertheless, in the hamster model, where the progression of tumors can be adequately examined, most pancreatic cancers develop within islets. Warren seems to have been the first to observe the development of malignant cells within islets in 1938 (41). This finding was either ignored or was interpreted as invasion of islets by cancer cells. Our anectodal observations indicate that this is also the case with human pancreatic cancer. The initial development of cancers within human islets was demonstrated in one of our recent studies. In two patients who died of gastric or renal cancer, we observed two microscopic cancers $(2.6 \times 0.7$ and $4 \times 2 \mathrm{~mm})$ at autopsy in the body of the pancreas. In both cases, cancer cells were primarily located within islets and extended into the periinsular areas invading the nerves (42). Similar to most pancreatic cancers, both of these microscopic lesions showed the mutation of the c-Ki-ras oncogene and expressed pancreatic cancer-associated antigens. Therefore, it is very likely that at least some human pancreatic cancers develop within islets.

Our observations along with studies on pancreatic endocrine and exocrine tissue let us assume that tumors, regardless of their phenotype, derive from pancreatic reserve (stem) cells, which are obviously distributed along the ductal system and within the islets. This concept best explains the occurrence of pancreatic tumors composed of mixed ductalinsular cancers (43-51) (Fig. 29), even in their metastatic sites (50).

Our data show that some components of islets are highly pluripotential and on pathological stimula- 
tion, give rise to a wide spectrum of orthotopic and heterotopic cells in animals and humans. Although many metaplastic changes in hamster islets have not been seen in the human pancreas, tumors composed of similar or identical cell phenotypes occur in some human pancreatic tumors. Because the lesions in hamsters are seen mostly during early stages of carcinogenesis, are multifocal, and can be observed often in one of the serial sections of the whole pancreas, their apparent absence in humans is selfexplanatory.

The insular cells from which the exocrine cells originate is obscure. Although the transdifferentiation of mature islets to other cell types has defenders (reviewed in $35,37,38$ ), considering the spectrum of cells of gastrointestinal origin produced within islets, the stem cell theory is more likely. The expression of fetal antigens in pancreatic tumors, including CEA, $\alpha$ - 1 antitrypsin (52), and $\alpha$-fetoprotein (53), supports this notion. It is noteworthy that most of the metaplastic cells initially develop in the islet periphery where normally islet replication takes place. Therefore, it is tempting to assume that periinsular ductular cells are the origin of these cells. However, as described above, in many cases, the lesions were within the boundary of islets, and no traces of periinsular ductules could be found, or if present, no connection to the insular tissue was evident. Consequently, some cells in the islet periphery seem to be more responsive to phenotypic changes than the cells in other pancreatic regions. The identity of these cells is unclear at the present time.

It appears that the differentiation state of pancreatic cells is mainly controlled at the transcriptional level and involves repression of islet cells and upregulation of ductal or acinar cell genes, and perhaps represssion of ductal and upregulation of islet cells. Seemingly, this "genetic switch" is more active in islet cells than in the exocrine cells. The recent identification of transcriptional factors involved in the differentiation of pancreatic cells, and especially of islet cells (54) could help the understanding of the 1000 faces of islets.

\section{Acknowledgments}

This work was supported by the National Institute of Health National Cancer Institute grant 5RO 1 CA60479, the National Cancer Institute Laboratory
Cancer Research Center support grant CA367127, and the American Cancer Society Special Institutional Grant.

\section{References}

1 Neubert K. Bau und entwicklung des menschlichen pankreas. Arch Entwicklungsmech Organ 1927; 111: 29.

2 Bencosme SA. The histogenesis and cytology of the pancreatic islets in the rabbit. Am J Anat 1955; 96:103-151.

3 Boquist L. Alloxan administration in the Chines hamster. II. Ultrstructural study of degeneration and subsequent regeneration of the pancreatic islet tissue. Virchows Arch B $1968 ; 1: 169$.

4 Lazarus SS, Volk BW. The Pancreas in Human and Experimental Diabetes. Grune \& Stratton, New York, 1968.

5 Ferner $\mathrm{H}$. Beiträge zur Histobiologie der Langerhansschen inseln des Menschen mit besonderer berücksichtigung der Silberzellen and ihrer beziehung zum Pankreas-diabetes. Virchows Arch Pathol Anat 1942; 309: 87-136.

6 Laidlaw GF. Nesidioblastoma, the islet tumor of the pancreas. Am J Pathol 1938; 14: 125-134.

7 Bensley RR. Studies on the pancreas of the guinea pig. Am $J$ Anat 1911; 12: 297.

8 Bloom W, Fawcett DW. in A Text Book for Histology, 9th ed, WB Saunders, Philadelphia, 1968, p. 614.

9 Pour PM. Islet cells as a component of pancreatic ductal neoplasms. I. Experimental study. Ductular cells, including islet cell precursors, and primary progenitor cells of tumors. Am J Pathol 1978; 90: 295-316.

10 Pour PM, Wilson R. Experimental pancreas tumor, in Cancer of the Pancreas, Moossa AR (ed.), Williams and Wilkins, Baltimore, London, 1980; pp. 37-158.

11 Pour PM. Histogenesis of exocrine pancreatic cancer in the hamster model. Envirorn Health Perspect 1984; 56 : 229-243.

12 Takahashi M, Pour PM. Spontaneous pancreas alteration in aging Syrian hamsters. I Natl Cancer Inst 1978; 60: 355-364.

13 Egami $H$, Takiyama $Y$, Chaney WG, Cano M, Fujii $H$, Tomioka $\mathrm{T}$, et al. Comparative studies on expression of tumors-associated antigens in humans and induced pancreatic cancer in Syrian hamster. Int J Pancreatol 1990; 7 : 91-100.

14 Pour PM, Sayed SE, Wolf GL. Considerations on the incidence of pancreatic cancer. Cancer Lett 1980; 10:151-154.

15 Pour PM, Sayed S, Sayed G, Wolf GL. Hyperplastic preneoplastic and neoplastic lesions found in 83 human pancreas. Am J Clin Pathol 1982; 77: 137-152.

16 Tomioka T, Andrén-Sandberg A, Fujii H, Egami H, Takiyama Y, Pour PM. Comparative histopathological findings in the pancreas of cigarette smokers and nonsmokers. Cancer Lett 1990; 55: 12 l-128.

17 Pour PM, Kazakoff K. Stimulation of islet cell proliferation enhances pancreatic ductal carcinogenesis in the hamster model. Am J Pathol 1996; 149: 1017-1025.

18 Pour PM, Kazakoff K. Carlson K. Inhibition of Streptozotocin-induced islet cell tumors and BOP-induced exoge- 
nous pancreatic tumors in Syrian hamsters. Cancer Res 1990; 50: 1634-1639.

$19 \mathrm{Kim} \mathrm{JH}$, Ho SB, Montgomery CK, Young SK. Cell lineage markers in human pancreatic cancer. Cancer 1990; 66: 2134-2143.

20 Feyrter F. Über die peripheren endokrinen (parakrinen) Drüsen des Menschen. V. Wisenschft, Wilhelm Maudrich, Wien-Düsseldorf, 1953.

21 Arihiro K, Inai $\mathrm{K}$. Malignant islet cell tumor of the pancreas with multiple hormone production and expression of CEA and CA19-9. Report of an autopsy case. Acta Pathol Jpn 1991; 41(2): 150-157.

22 Kniffin WD, Spencer SK, Memoli VA, LeMarbre PJ Metastatic islet cell amphicrine carcinoma of the pancreas. Cancer 1988; 62: 1999-2004.

23 Ordóñez NG, Balsaver AM, Mackay B. Mucinous islet cell (amphicrine) carcinoma of the pancreas associated with watery diarrhea and hypokalemia syndrome. Hum Pathol 1988; 19: 12.

24 Cossel L. Intermediärzellen im pankreas und zelluläre transformation. Zentralbl Allg Pathol Anat 1987; 133: 503-516.

25 Scarpelli DG, Rao MS. Differentiation of regenerating pancreatic cells into hepatocytelike cells. Proc Natl Acad Sci USA 1981; 78 2577-2581.

26 Rao MS. Subbarao V, Reddy JK. Induction of hepatocytes in the pancreas of copper-depleted rats following repletion. Cell Diff 1986; 18: 109-117.

27 Konishi N, Ward JM, Waalkes M. Pancreatic hepatocytes in Fischer and Wistar rats induced by repeated injections of cadmium chloride. Toxicol Appl Pharmacol 1990; 104, 149-156.

28 Tsanadis G, Kotoulas O, Lollis D. Hepatocyte-like cells in the pancreatic islets: study of the human fetal pancreas and experimental models. Histol Histopathol 1995; 10: 1-10.

29 Hamperl $\mathrm{H}$. Benign and malignant oncocytoma. Cancer 1962; 15: 1019-1062.

30 Munger BL. The ultrastructure of the exocrine pancreas, in The Pancreas, Cary LC (ed.), CV Mosby, St. Louis, 1973; pp. 17-31.

31 Hamoudi AB, Misugi K, Grosfeld JL, Reiner CB. Papillary epithelial neoplasm of pancreas in a child. Cancer 1970; 26: 1126-1134

32 Cubilla AL, Fitzgerald PJ. Tumors of the exocrine pancreas, in Atlas of Tumor Pathology, 2nd ser., Fascicle 19 Armed Forces Institute of Pathology, Washington, DC, 1984.

33 Priesel A. Über ein ungewöhnliches Gewächs der Bauchspeiseldrüse. Virchows Arch Pathol Anat 1928; 267 : 354-362.

34 Cubilla AL, Fitzgerlad PJ. Surgical pathology of tumors of the exocrine pancreas, in Tumors of the Pancreas, Moossa, AB (ed.) Williams \& Wilkins, Baltimore, 1980: pp. 159-193.

35 Liu G, Schmied B, Moyer MP, Weide L, Murphy L, Pour PM. Formation of pancreatic exocrine cells from cultured hamster islets. Submitted.

36 Kerr-Conte J, Pattou F, Lecomte M, Xia Y, Boilly B, Proye $C$, et al. Ductal cystic formation in collagen-embedded adult human islet preparations. Diabetes 1996; 45: 1108-1114.
37 Yuan S, Rosenberg L, Paraskevas S, Agapitos D, Duguid WP. Transdifferentiation of human islets to pancreatic ductal cells in collagen matrix culture. Differentiation 1996 61: $67-75$.

38 Bouwens L, De Blay E. Islet morphogenesis and stem cell markers in rat pancreas. J Histochem Cytochem 1996; 44: 947-951.

39 Pour PM, Weide L, Liu G, Kazakoff K, Scheetz M, Toshkov I, et al. Experimental evidence for the origin of ductal type adenocarcinoma from the islets of Langerhans. AmJ Pathol 1997; 150: 2167-2180.

40 Yamao K, Nakazawa S, Fujimoto M, Yamada M, Milchgrub S, Albores-Saavedra J. Intraductal papillary mucinous tumors, non-invasive and invasive, in Atlas of Exocrine Pancreatic Tumors. Morphology, Biology and Diagnosis with an International Guide for Tumor Classification. Pour P, Konishi Y, Klöppel G, Longnecker DS (eds.), Springer, Verlag, Japan, 1994: pp. 117-154.

41 Warren S. The Pathology of Diabetes Mellitus. Lea \& Febigere, Philadelphia, 1938: p. 25.

42 Kimura W, Morikane K, Esaki Y, Chan WC, Pour PM. Histological and biological patterns of microscopic ductal adenocarcinomas detected incidentally at autopsy. Cancer 1998; 82: 1839-1849.

43 Kashiwabara K, Nakajima T, Shinkai H, Fukuda T, Oono $\mathrm{Y}$, Kurabayashi $\mathrm{X}$, et al. A case of malignant duct-islet cell tumor of the pancreas immunohistochemical and cytofluorometric study. Acta Pathol Jpn 1991; 41(8): 636-641.

44 Kodama T, Mori W. Morphological behavior of carcinomas of the pancreas. 2. Argyrophil cells and langerhans islets in the carcinomatous tissues. Acta Pathol Jpn 1983; 33(3): 483-493.

45 Minkus G, Breuer W, Arun S, Kirsch M, Müller, Jueller J, et al. Ductuloendocrine cell proliferation in the pancreas of two young dogs with diabetes mellitus. Vet Pathol 1997; 34: $164-167$

46 Pour PM, Permert J, Mogaki M, Fujii H, Kazakoff K. Endocrine aspects of exocrine cancer of the pancreas. Their patterns and suggested biological significance. Am J Clin Pathol 1993; 100 :223-230.

47 Pour PM, Morohoshi T. Ductal adenocarcinoma, in Atlas of Exocrine Pancreatic Tumors. Morphology, Biology and Diagnosis with an International Guide for Tumor Classification, Springer Verlag, Japan, 1994; pp. 117-154.

48 Reid JD, Yuh S-L. Petrelli M, Jaffe MB. Ductuloinsular tumors of the pancreas. Cancer 1992; 49: 908-915.

49 Schlosnagle DC, Campbell WG. The papillary and solid neoplasm of the pancreas: A report of two cases with electron microscopy, one containing neurosecretory granules. Cancer 1981; 47(11): 2603-2610.

50 Eusebi V, Capella C, Bondi A, Sessa F, Vezzadinia P, Mancini AM. Endocrine-paracrine cells in pancreatic exocrine carcinomas. Histopathology 1981: 5: 599-613.

51 Nonomura A, Mizukami Y, Matsubara F. Kono N, Nakanuma Y. Duct-islet cell tumor of the pancreas. Acta Pathol Jpn 1989; 39: 328-335.

52 Callea F, Goddeeris P, Mukunda RB, Geboes K. Bekaert $J$, Desmet VJ. Presenece of alpha-1-antitrypsin in pancre- 
atic carcinoma. Report of four cases with hepatic storage of the protease inhibitor. Appl Pathol 1983; 1:290-300.

53 Tanno S, Obara $T$, Shudo R, Fujii T, Sugawara K, Nishino $N$, et al. $\alpha$-Fetoprotein producing mucin-producing carcinoma of the pancreas. A case report with immunohisto- chemical study and lectin-affinity profile. Dig Dis Sci 1997 ; 42: 2513-2518.

54 Gu D, Lee M-S, Krahl T, Sarvetnick N. Transitional cells in the regenerating pancreas. Development 1994; 120 : $1873-1881$ 